\title{
Modelling of a falling sludge bed reactor using AQUASIM
}

\author{
NE Ristow* and GS Hansford \\ Department of Chemical Engineering, University of Cape Town, Rondebosch 7701, South Africa
}

\begin{abstract}
The falling sludge bed reactor (FSBR) allows for increased solids retention time, resulting in greater substrate conversion for all particulate degradation and biological reactions. The purpose of the FSBR is to hydrolyse primary settled sewage (PSS). Soluble products are then used for the biological treatment of acid mine drainage. A mathematical model has been developed that describes the anaerobic digestion of PSS and biological sulphate reduction in the FSBR. The hydrodynamic processes taking place in the FSBR have been simulated using a system of mixed reactors connected by water flow and mass flux streams. Trends obtained from varying the hydraulic retention time, the sludge recycle ratio, and the feed $\mathrm{COD}: \mathrm{SO}_{4}^{2-}$ ratio allow for identification of the critical biological processes taking place in the FSBR, as well as the influence of the operating parameters. Areas where there is a lack of understanding in the mechanism and kinetics have been identified, and these include the influence of sulphate reduction on the hydrolysis of particulate organic matter, as well as the mathematical influence of sulphide inhibition on the various biological groups. A sensitivity analysis shows that hydrolysis is the rate-limiting process, while sulphide inhibition is of importance when sulphate conversion increases.
\end{abstract}

\section{Introduction}

Acid mine drainage (AMD) characteristically consists of high concentrations of heavy metals $\left(\mathrm{Al}=50\right.$ to $2000 \mathrm{mg} \cdot \ell^{-1} ; \mathrm{Fe}=10$ to $6700 \mathrm{mg} \cdot \ell^{-1} ; \mathrm{Zn}=10$ to $\left.100 \mathrm{mg} \cdot \ell^{-1}\right)$, sulphate $\left(3000\right.$ to $\left.30000 \mathrm{mg} \cdot \ell^{-1}\right)$ and total dissolved solids ( 1800 to $45000 \mathrm{mg} \cdot \ell^{-1}$ ), coupled with a low pH (2 to 3) (Christensen et al., 1996). Biological sulphate reduction is an attractive option for the treatment of AMD. Sulphate reduction directly reduces salinity and protons, producing alkalinity in the form of sulphide, and allowing the precipitation of the heavy metals as metal sulphides or hydroxides. Organic electron donors that have been tested for sulphate reduction include producer gas (Du Preez et al., 1992; Van Houten et al., 1994), intermediatelength carbon chain compounds like ethanol and methanol (Postgate, 1984; Braun and Stolp, 1985; Szewzyk and Pfennig, 1990) and complex compounds such as sewage sludge (Butlin et al., 1956; Pipes, 1960; Burgess and Wood, 1961; Conradie and Grutz, 1973), animal waste slurries (Ueki et al., 1988), lactate and cheese whey (Oleszkiewicz and Hilton, 1986) and molasses (Maree and Hill, 1989).

The Rhodes BioSURE Process used primary settled sewage (PSS) as the electron donor. The AMD was blended with the PSS at a fixed COD: $\mathrm{SO}_{4}^{2-}$ ratio, before being fed to the falling sludge bed reactor (FSBR) which had been seeded with sulphate-reducing bacteria (SRB). The aim of the FSBR was to hydrolyse the particulate organic matter, producing volatile fatty acids (VFAs). The soluble products and sulphate then entered a baffled reactor, where the majority of the sulphate reduction took place. The effluent from the baffled reactor went into an algal-ponding system as a polishing step. Before integration of the process could be performed to include recycling of the alkalinity that is generated, mathematical modelling of the individual unit operations was required. This study focused specifically on the FSBR.

Sulphate-reducing bacteria cannot use particulate or complex soluble organic matter directly. Therefore, they rely on acidogenic

\footnotetext{
* To whom all correspondence should be addressed.

蒕082 327 2737; fax: (021) 689 7471; e-mail: neilristow@ hotmail.com

Received 23 March 2001; accepted in revised form 12 July 2001.
}

bacteria to reduce the long-chain organics to short-chain volatile fatty acids and alcohols. These acidogenic bacteria hydrolyse the particulate organics extracellularly, taking up complex soluble organics and producing short-chain organics. The rate of hydrolysis is dependent on the concentration of this group of bacteria as well as the particulate organic concentration. Therefore, by designing a bioreactor in which a high solids retention time is possible, coupled with a low hydraulic retention time, the conversion of particulates to soluble products can be maximised. The FSBR allows for the internal recycle of settled particulates, uncoupling the solids and hydraulic retention times. This takes place by the settling of the solid matter into three valleys inside the reactor, as opposed to an external settling unit with sludge recycle.

Khan and Trottier (1978) concluded that the presence of reduced sulphur species is essential for the degradation of cellulose. Laboratory studies have also shown an increase in hydrolysis conversion of PSS in the presence of sulphate-reducing bacteria (Wittington-Jones, 1999). Pareek et al. (1998) showed an increase in the conversion of cellulosic materials under sulphate-reducing conditions. By operating the hydrolysis reactor in the presence of biological sulphate reduction, an increased rate of hydrolysis was expected.

Modelling of the biological reactions and the hydrodynamic variations in the FSBR would identify the critical processes taking place within the reactor, as well as highlight areas where further experimentation on this system is required. The kinetic model was developed from a combination of existing models from the literature. A computer program called AQUASIM was used to integrate the rate equations for the various biological and chemical processes. AQUASIM was designed for the identification and simulation of aquatic systems in the laboratory, in technical plants and in nature (Reichert, 1994). It has been applied to a number of biological systems, the majority of these involving nutrient removal by activated sludge. In this study, AQUASIM was applied to a biological sulphate-reduction process. 


\section{Model development}

To model the system, the reaction scheme, rate equations and kinetic constants for the processes taking place in the FSBR were chosen from published models on anaerobic digestion and sulphate reduction. The kinetic model was based on the work of five researchers (O’Rourke, 1968; Eastman and Ferguson, 1981; Gujer and Zehnder, 1983; Costello et al., 1991; Kalyuzhnyi and Fedorovich, 1998), where aspects from each published model were

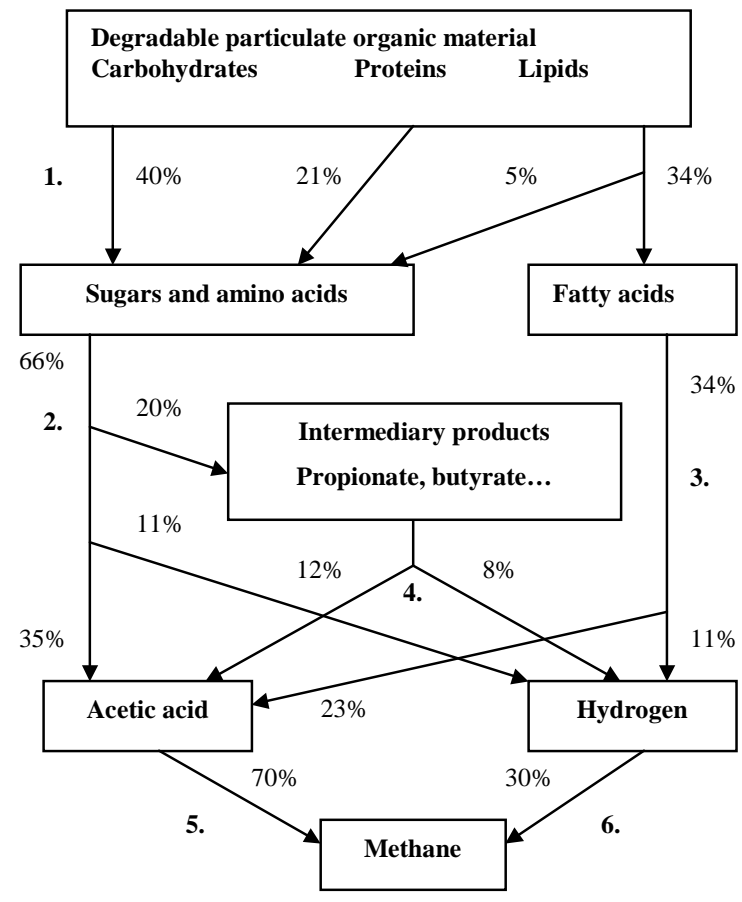

Figure 1

Reaction scheme from Gujer and Zehnder (1983) for the anaerobic digestion of domestic sludge, where percentages indicate substrate flow (stoichiometrically) in the form of COD equivalents. Only the net flow of substrates through cell pools is indicated. The numbers refer to the six biological processes

(1. hydrolysis; 2. fermentation; 3. anaerobic oxidation;

4. acetogenesis; 5 . acetoclastic methanogenesis; 6. hydrogenotrophic methanogenesis). included. The composition of the PSS for the model was taken from Eastman and Ferguson (1981) (protein $28.7 \%$ of total COD, carbohydrate $19.9 \%$, lipids $21.0 \%$, VFA $5.0 \%$, ash $26.5 \%$ ). The reaction scheme proposed by Gujer and Zehnder (1983), based on the work of Kasper and Wuhrmann (1977) was chosen for the anaerobic digestion of particulate organic matter, from hydrolysis to methane production.

Superimposed on Fig. 1 are three groups of SRB consuming propionate, acetate or hydrogen, in competition with the acetogens and methanogens. By modelling all of the possible processes in the degradation of PSS, rate-limiting processes could be identified, so that the next generation of models could ignore the more rapid and rigorous processes.

The rate equations were chosen from the literature for each of the reactions. For the hydrolysis reactions, a first-order rate equation with respect to the particulate COD concentration was used (O'Rourke, 1968). It was accepted that the first-order rate equation would be inadequate in predicting the rate of hydrolysis, since this rate is dependent on the acidogenic biomass concentration and other influences from the sulphate-reducing conditions. However, published rate equations predicting these interactions could not be found.

To determine the growth of the various groups of bacteria, the model proposed by Kalyuzhnyi and Fedorovich (1998) was used as a basis, since it was developed for the degradation of a mixture of sucrose, propionate, acetate and sulphate. The rate equations included terms for sulphide inhibition in all of the reactions, as well as sulphate limitation in the three sulphate-reducing reactions. The rate equation for the anaerobic oxidation of the long chain fatty acids was modified from the Monod equation, where a sulphide inhibition term was included. A competitive acetic acid inhibition term was included for the fermentation reaction, while a noncompetitive acetic acid inhibition term was included for the acetogenic reaction (Costello et al., 1991).

A summary of the reactions, their rate equations and kinetic constants is shown in Table 5. Table 6 shows the matrix representation of the degradation of PSS in the presence of sulphate reduction. The kinetic constants from all of these references were for processes taking place at $35^{\circ} \mathrm{C}$, while the pilot-plant ambient temperature was at $15^{\circ} \mathrm{C}$. To adjust the operating temperature of the model from $35^{\circ} \mathrm{C}$ to roughly $15^{\circ} \mathrm{C}$, the maximum specific growthrate constants and hydrolysis rate constants were all divided by 4 . This conforms to the typical Arrhenius-type temperature dependence of anaerobic bacteria, where the maximum specific growth rate could be expected to halve with a $10^{\circ} \mathrm{C}$ drop in temperature.

The concentrations of the undissociated inhibitory species $\left(\left[\mathrm{H}_{2} \mathrm{~S}\right]\right.$ and $\left.[\mathrm{HAc}]\right)$ were calculated from the total sulphide and acetate concentrations using the acid-base equilibrium constants, following Musvoto et al. (1997). A constant $\mathrm{pH}$ of 7 was chosen for the entire system, since insufficient data was available to calibrate this detail in the mathematical model.

\section{Reactor configuration}

Figure 2 shows the configuration of the FSBR. Analysis showed that the solids density decreased from the feed to the effluent of the FSBR,

Figure 2

The configuration of the FSBR pilot plant 
Physical Bioreactor Station

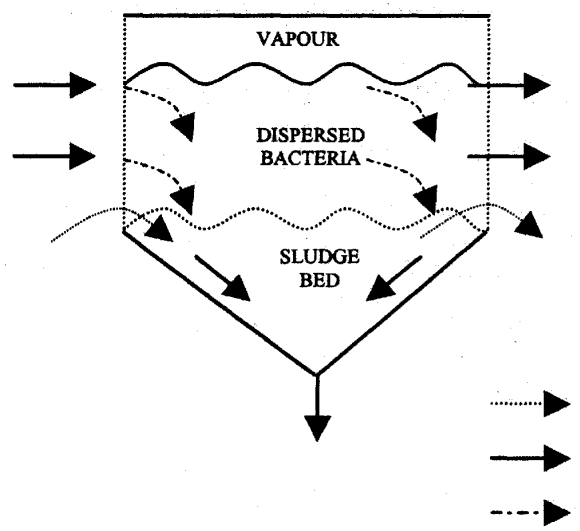

AOUASIM Representation

SLUDGE OVERFLOW

LIQUID FLOW

SETTLING SOLIDS

Figure 3

The flow patterns taking place in one section of the reactor, and the subsequent representation of this section in AQUASIM

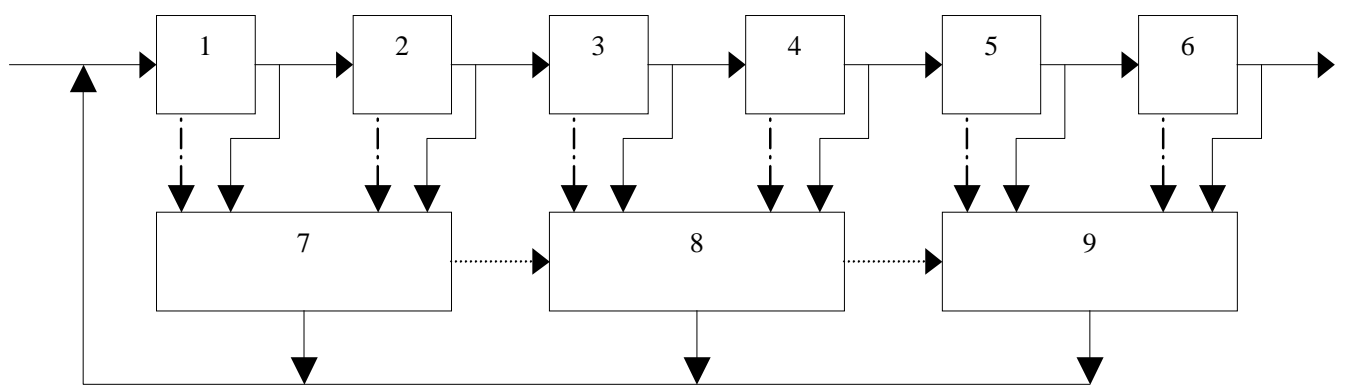

Figure 4

The AQUASIM representation of the FSBR showing the compartments and the connecting streams

and increased from the top to the bottom of any valley. There was also a variation of total COD in the three valleys, due to the different recycle rates from each valley, as well as the differential settling of larger particulates into the first valley. The soluble substrate concentrations decreased along the length of the FSBR, as the reaction time and substrate conversion increased.

In order to simulate these variations, mixed reactor compartments were used from AQUASIM. The volume of the FSBR was divided into nine of these compartments (Fig. 2), connected by water flow streams and mass flux streams. This configuration allows for plug flow of the liquid and dissolved components across the top of the reactor, with settling of the solids into the three valleys.

The model makes use of three different streams to represent the different flow patterns in the reactor. The first is the flow of water with the dissolved compounds and the particulates from the inlet compartment to the outlet, as well as to the three valleys due to the recycle (Fig. 3). The flow of water in each of the valleys was determined from the time that the recycle pump pumped from that valley $(60 \mathrm{~s}, 30 \mathrm{~s}$ and $10 \mathrm{~s}$ from valleys 1,2 and 3 respectively). For the model, the overall pump flow rate was weighted from each of the valleys according to the time the pump draws from that valley.

The second type of stream used in the model shows the settling of the particulates into the valleys. This velocity profile is superimposed on the liquid flow, due to the differential gravitational forces on the particulates (Fig. 3). The larger particles will settle faster than the smaller ones, and preferentially into the first of the three valleys. There is also a higher recycle and liquid flow rate into the first valley due to the extended draw period, resulting in more solids flowing into this valley.

The final stream used in the model represents the overflow of particulate matter from one valley to the next. This is due to the filling of the first valley caused by the immediate settling of the majority of the particulates, thereby causing the sludge bed to overflow to the adjacent valley. It is also partially due to the liquid movement across the top of the valleys, causing the particles to spill into the next valley.

Figure 3 illustrates the flow patterns taking place in one section of the reactor, and the subsequent representation of this section in AQUASIM. The complete reactor configuration used in the model is shown in Fig. 4.

\section{Model calibration}

The model was calibrated using data obtained from the pilotFSBR, which was operated for 18 months at three operating conditions (approximate feed COD: $\mathrm{SO}_{4}{ }^{2-}$ ratio of 1.5, 2 and $3 \mathrm{~g} \mathrm{COD} / \mathrm{g}$ ). Samples were collected daily (except weekends) and analysed for sulphate, acetate and total COD. Three steady-state operating points were identified (Table 1), where the criterion for steady state was a maximum variation of $10 \%$ in the measured data for a minimum operating period of three hydraulic retention times (> $4.7 \mathrm{~d})$.

In order to calibrate the settling of the solids, spatial variation data were required. For a steady-state operating point, the total COD in each of the three valleys was measured (Table 2). By predicting these total COD concentrations, the settling coefficients used to superimpose solids settling on the liquid-flow streams 
could be calibrated.

Table 3 shows that the model accurately predicts the total COD measured in each of the three valleys. Furthermore, the effluent sulphate concentration predicted by the model was within $34 \%$ of

\begin{tabular}{|c|c|c|c|}
\hline \multicolumn{4}{|c|}{ TABLE 1 } \\
\hline \multicolumn{4}{|c|}{ Summary of the steady state operating data } \\
\hline $\begin{array}{c}\text { Feed } \\
\text { COD: SO } \\
\text { ratio }\end{array}$ & $\begin{array}{c}\text { Feed sulphate } \\
\text { concentration } \\
\left(\mathbf{g} \cdot \mathbf{m}^{-3}\right)\end{array}$ & $\begin{array}{c}\text { Feed COD } \\
\text { concentration } \\
\left(\mathbf{g C O D} \cdot \mathbf{m}^{-3}\right)\end{array}$ & $\begin{array}{c}\text { Effluent } \\
\text { sulphate } \\
\text { concentration } \\
\left(\mathbf{g} \cdot \mathbf{m}^{-3} \mathbf{)}\right.\end{array}$ \\
\hline $2: 1$ & $1718 \pm 107$ & $3390 \pm 238$ & $970 \pm 41$ \\
$1.5: 1$ & $1777 \pm 27$ & $2646 \pm 24$ & $\begin{array}{c}496 \pm 172 \\
820 \pm 171\end{array}$ \\
$3: 1$ & $1604 \pm 101$ & $4728 \pm 557$ & $820 \pm 1$ \\
\hline
\end{tabular}

the measured values for these operating conditions.

In spite of the limitations discussed regarding the rate equation used for hydrolysis and the adjusted values for the maximum growth rates and hydrolysis-rate constants due to the temperature differences between the literature conditions and the pilot-plant operating conditions, the model still predicted a credible effluent sulphate concentration. This means that the trends predicted by the model could be expected to be realistic.

The two steady-state points in Table 4 were used to get some indication of whether the model is predicting realistic results, and these two operating conditions were simulated. Table 4 compares the simulated data to the measured data for these two operating conditions.

Table 4 shows that the model predicts the performance of the FSBR pilot plant at these operating conditions, knowing the limitations of the hydrolysis rate equation. The rest of the rate equations and kinetic constants used are adequate in modelling the biological reactions taking place in the FSBR.

\section{TABLE 2}

Total COD measurements from each of the three valleys when operating at a COD:SO ratio of 2

\begin{tabular}{|c|c|c|c|c|}
\hline & $\begin{array}{c}\text { Concentration 1 } \\
\left(\mathbf{g C O D} \cdot \mathbf{m}^{-3}\right)\end{array}$ & $\begin{array}{c}\text { Concentration 2 } \\
\left(\mathbf{g C O D} \cdot \mathbf{m}^{-3}\right)\end{array}$ & $\begin{array}{c}\text { Average } \\
\left(\mathbf{g C O D} \cdot \mathbf{m}^{-3}\right)\end{array}$ & $\%$ Variation \\
\hline Valley 1 & 59600 & 64000 & $61800 \pm 2200$ & 3.43 \\
Valley 2 & 45600 & 54500 & $50050 \pm 4450$ & 8.16 \\
Valley 3 & 40300 & 67000 & $53650 \pm 13350$ & 19.9 \\
\hline
\end{tabular}

TABLE 3

Comparison of measured and simulated concentrations to calibrate the settling coefficients in the model

\begin{tabular}{|l|c|c|c|}
\hline Sample point & $\begin{array}{c}\text { Measured } \\
\text { value }\end{array}$ & $\begin{array}{c}\text { Simulated } \\
\text { value }\end{array}$ & $\begin{array}{c}\% \\
\text { Variation }\end{array}$ \\
\hline valley $1\left(\mathrm{gCOD} \cdot \mathrm{m}^{-3}\right)$ & 61800 & 61500 & 0.46 \\
valley 2 $\left(\mathrm{gCOD} \cdot \mathrm{m}^{-3}\right)$ & 50050 & 50900 & 1.67 \\
valley $3\left(\mathrm{gCOD} \cdot \mathrm{m}^{-3}\right)$ & 53650 & 52000 & 3.07 \\
\hline effluent sulphate & $970 \mathrm{mg} \cdot \ell^{-1}$ & $1300 \mathrm{mg} \cdot \ell^{-1}$ & 34.0 \\
concentration & & & \\
\hline
\end{tabular}

TABLE 4

Comparisons of measured values to simulated values for verification of the model

\begin{tabular}{l|c|c|c}
$\mathrm{COD}: \mathrm{SO}_{4}^{2-}$ & $2: 1$ & $1.33: 1$ & $2.82: 1$ \\
$\mathrm{COD}$ in $\left(\mathrm{gCOD} \cdot \mathrm{m}^{-3}\right)$ (meas.) & 3390 & 2646 & 4728 \\
sulphate in $\left(\mathrm{mg} \cdot \ell^{-1}\right)$ (meas.) & 1718 & 1777 & 1604 \\
sulphate out $\left(\mathrm{mg} \cdot \ell^{-1}\right)$ (meas.) & 970 & 1496 & 820 \\
simulated sulphate out (mg. $\left.\ell^{-1}\right)$ & 1300 & 1481 & 1048 \\
$\%$ deviation in sulphate out & 34.0 & 1.00 & 27.8
\end{tabular}

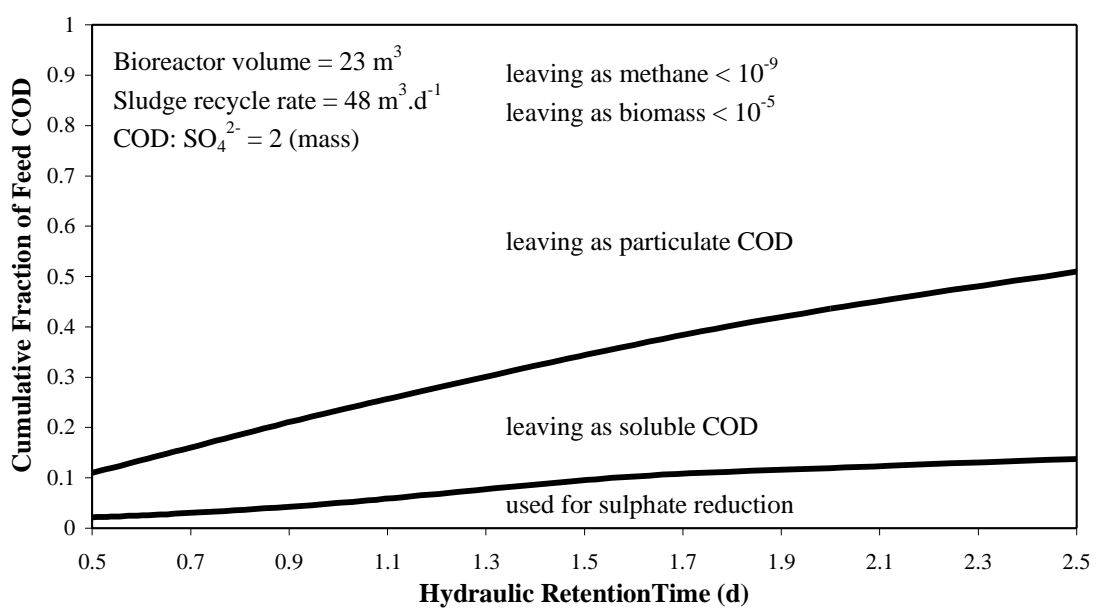

Figure 5

Model predictions of the

fraction of the feed $C O D$ that is leaving the bioreactor as particulate $C O D$, soluble $C O D$, biomass, methane and sulphide, as the feed rate to the bioreactor is varied, varying the hydraulic retention time $\left(\mathrm{COD}: \mathrm{SO}_{4}^{2-}=2\right)$ 
amount of methane produced, and finally the amount that has been used for sulphate reduction.

Trends have been obtained from varying three operating conditions, namely the hydraulic retention time (HRT), the sludge recycle ratio (SRR), and the $\mathrm{COD}: \mathrm{SO}_{4}^{2-}$ ratio of the feed. To vary the HRT, the feed pump rate was varied from $46 \mathrm{~m}^{3} \cdot \mathrm{d}^{-1}$ to $9.2 \mathrm{~m}^{3} \cdot \mathrm{d}^{-1}$ $(\mathrm{HRT}=0.5$ to $2.5 \mathrm{~d})$. The sludge recycle ratio was varied by varying the recycle pump rate from $3.66 \mathrm{~m}^{3} \cdot \mathrm{d}^{-1}$ to $58.56 \mathrm{~m}^{3} \cdot \mathrm{d}^{-1}(\mathrm{SRR}=0.25$ to 4). Finally, the feed COD: $\mathrm{SO}_{4}^{2-}$ was varied ( 0.5 to 4 ) by varying the COD concentration from $850 \mathrm{gCOD} \cdot \mathrm{m}^{-3}$ to $6800 \mathrm{gCOD} \cdot \mathrm{m}^{-3}$. Figures 5 to 7 show the cumulative fractions of the various components of the effluent total COD (particulate species, biomass species, sulphide species, soluble species, and methane), while varying the HRT, SRR and COD: $\mathrm{SO}_{4}^{2-}$ ratio respectively. The lines in Figs. 5 to 7 separate the various fractions leaving the FSBR as predicted by the model. Therefore, at a HRT of $1.5 \mathrm{~d}$, approximately $10 \%$ of the feed COD has been used for sulphate reduction; approximately $30 \%( \pm$ $40 \%- \pm 10 \%$ ) as soluble COD, and the rest $(100 \%- \pm 40 \%=60 \%)$ as particulate COD. The percentage leaving as methane $\left(10^{-9}\right)$ and biomass $\left(10^{-5}\right)$ was insignificant, and does not appear as a fraction in Fig. 5.

In order to improve the performance of the bioreactor, the fraction that is leaving as particulate COD and as methane needs to be reduced, while the ratios between the fractions leaving as sulphide, soluble COD or biomass are of secondary importance. Common to Figs. 5 to 7 is that the model predicts insignificant amounts of biomass and methane being produced. Therefore, the model predicts that addition of sulphate to the FSBR eliminates the formation of methane. Also, due to the low yield values of anaerobic bacteria, biomass production is insignificant.

Figure 5 shows that the model predicts that an increase in the HRT will decrease the fraction of particulate COD in the product stream. The fraction leaving as sulphide increases significantly from an HRT of 0.5 until around 1.7, when the amount seems to remain constant. The fraction leaving as soluble COD increases substantially as the HRT is increased across the whole range. The decrease in the fraction leaving as particulate COD could be expected since the rate of hydrolysis is first order with respect to the particulate COD concentration, and an increase in the HRT would allow for an increased reaction time, which would, in turn, lead to greater conversion of particulate COD.

The fraction of the COD that is leaving the bioreactor as sulphide also increases with an increase in the HRT, but the curve seems

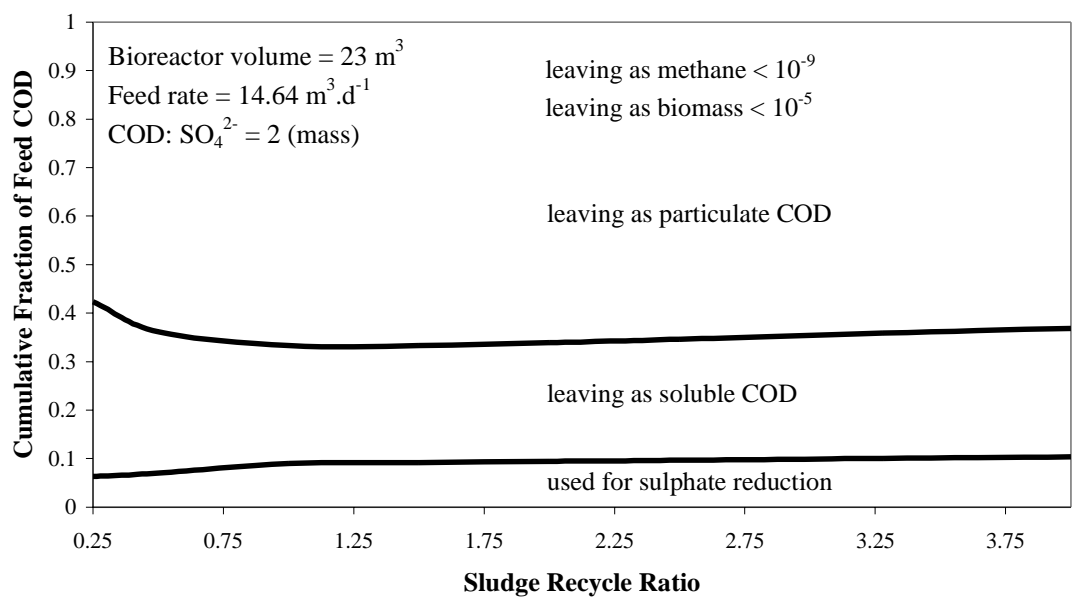

Figure 6

Model prediction of the fraction of the feed COD leaving the FSBR as particulate $C O D$, soluble $C O D$, biomass, methane, or used for sulphide reduction, as a function of the $S R R\left(H R T=1.57 ; \mathrm{COD}: \mathrm{SO}_{4}{ }^{2-}=2\right)$

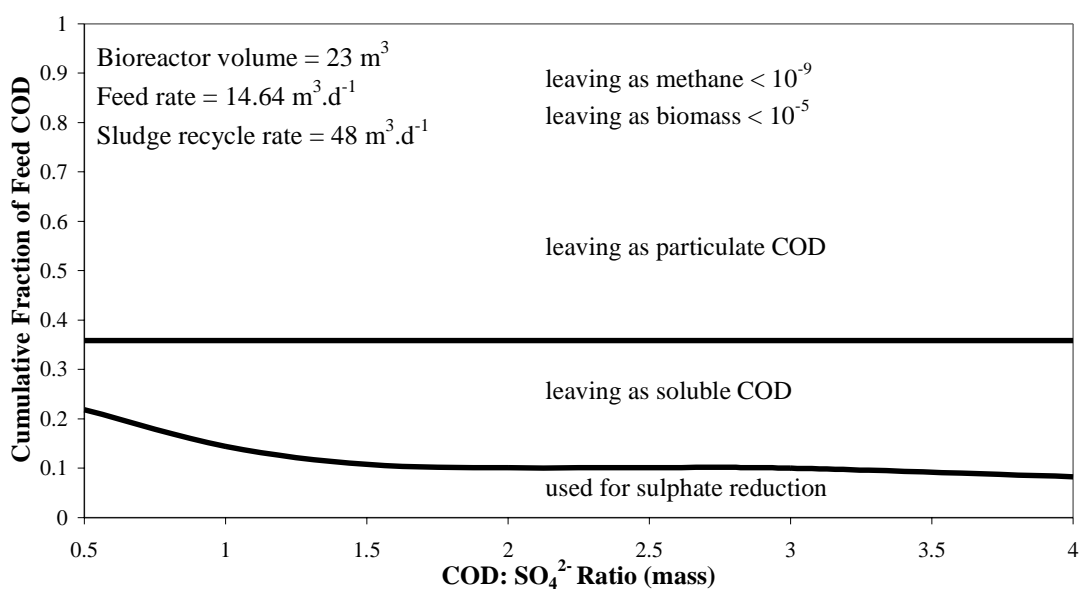

Figure 7

Model prediction of the fraction of feed COD that is leaving the bioreactor as either particulate $C O D$, soluble $C O D$, biomass, methane or sulphide, at various $C O D: \mathrm{SO}_{4}{ }^{2}$ ratios $(H R T=1.57 ; S R R=3.28)$

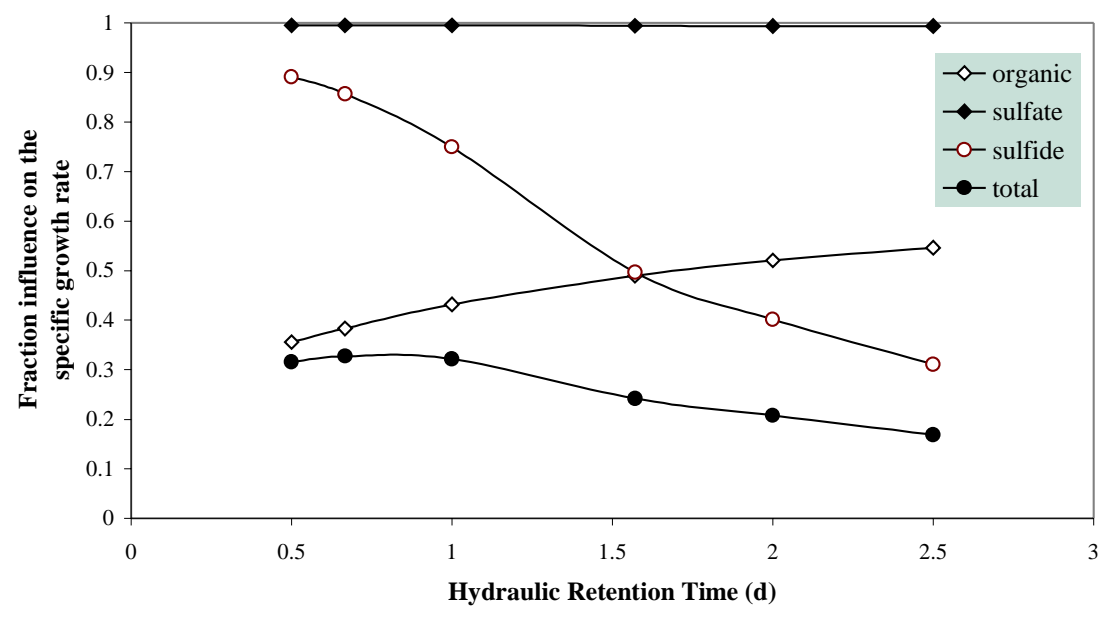

Figure 8

Model predictions of the terms for substrate limitation, sulphate limitation, sulphide inhibition, and the product of the three terms, for the acetogenic sulphidogens, as the feed to the bioreactor is varied by varying the hydraulic retention time $\left(C O D: S_{4}{ }^{2-}=2\right)$ 


\begin{tabular}{|c|c|c|c|c|}
\hline \multicolumn{5}{|c|}{$\begin{array}{c}\text { TABLE } 5 \\
\text { A summary of the reactions, rate equations, stoichiometry and kinetic constants used in the model }\end{array}$} \\
\hline Process & Reaction & Rate equation & Constants & References \\
\hline hydrolysis of proteins & proteins $\rightarrow$ amino acids & $r_{\text {proteins }}=k_{h_{\text {protein }}}[$ protein $]$ & $\mathrm{k}_{\mathrm{h}_{\text {protein }}}=0.0375 \mathrm{~d}^{-1}$ & O’Rourke (1968) (adjusted) \\
\hline hydrolysis of lipids & lipids $\rightarrow$ long chain fatty acids & $r_{\text {lipids }}=k_{h_{\text {lipus }}} \cdot[$ [lipids $]$ & $\mathrm{k}_{\mathrm{h}_{\text {hipids }}}=0.0425 \mathrm{~d}^{-1}$ & O’Rourke (1968) (adjusted) \\
\hline hydrolysis of cellulose & cellulose $\rightarrow$ sugars & $r_{\text {cellulose }}=k_{h_{\text {cellubore }}} \cdot[$ cellulose $]$ & $\mathrm{k}_{\mathrm{h}_{\text {cellulusese }}}=0.0525 \mathrm{~d}^{-1}$ & O’Rourke (1968) (adjusted) \\
\hline fermentation & $\begin{array}{l}\text { sugars }+ \text { amino acids } \rightarrow \\
\text { propionate }+ \text { acetate }+ \text { hydrogen }\end{array}$ & $\mu_{f}=\frac{\mu_{\max , f} C_{f}}{\left(1+\frac{K_{S, f}}{[S A A]}\right)\left(1+\frac{[H A c]}{K_{I f, H A c}}\right)}\left(1-\frac{\left[H_{2} S\right]}{K_{I f, H_{2} S}}\right)$ & $\begin{array}{l}\mu_{\max , \mathrm{f}}=2.0 \mathrm{~d}^{-1} \\
\mathrm{~K}_{\mathrm{S}, \mathrm{f}}=28 \mathrm{gCOD} \cdot \mathrm{m}^{-3} \\
\mathrm{Y}_{\mathrm{f}}=0.043 \mathrm{gVSS} \cdot \mathrm{gCOD}^{-1} \\
\mathrm{~K}_{\mathrm{K}}=0 . \mathrm{H}, \mathrm{HS}=550 \mathrm{~g} \mathrm{~S} \cdot \mathrm{m}^{-3} \\
\mathrm{~K}_{\mathrm{If}, \mathrm{HAc}}=604 \mathrm{gCOD} \cdot \mathrm{m}^{-3}\end{array}$ & $\begin{array}{l}\text { Kinetic constants and sulphide inhibition } \\
\text { from Kalyuzhnyi and Fedorovich (1998) } \\
\text { Acetate inhibition equation and constant } \\
\text { from Costello et al. (1991) } \\
\left(\mu_{\max } \text { adjusted) }\right.\end{array}$ \\
\hline anaerobic oxidation & $\begin{array}{l}\text { long chain fatty acids } \rightarrow \\
\text { acetate }+ \text { hydrogen }\end{array}$ & $\mu_{o}=\frac{\mu_{\text {max }, o} C_{o}}{\left(1+\frac{K_{S, o}}{[F A]}\right)}\left(1-\frac{\left[H_{2} S\right]}{K_{l o}}\right)$ & $\begin{array}{l}\mu_{\text {max. }}=0.1375 \mathrm{~d}^{-1} \\
\mathrm{~K}_{\mathrm{S}, 0}=1.816 \mathrm{gCOD} \cdot \mathrm{m}^{-3} \\
\mathrm{Y}_{\mathrm{o}}=0.11 \mathrm{gVSS} \cdot \mathrm{gCOD}^{-1} \\
\mathrm{~K}_{\mathrm{L}, 0}=550 \mathrm{~g} \mathrm{~S} \cdot \mathrm{m}^{-3}\end{array}$ & $\begin{array}{l}\text { Kinetic constants from Novak and } \\
\text { Carlson (1970) } \\
\text { Estimated sulphide inhibition constant } \\
\left(\mu_{\max } \text { adjusted }\right)\end{array}$ \\
\hline $\begin{array}{l}\text { aceticlastic } \\
\text { sulphidogenesis }\end{array}$ & $\begin{array}{l}\text { propionate }+ \text { sulphate } \rightarrow \\
\text { acetate }+ \text { sulphide }\end{array}$ & $\mu_{p s}=\frac{\mu_{\text {max }, p s} C_{p s}}{\left(1+\frac{K_{S, p s}}{[H \mathrm{Pr}]}\right)\left(1+\frac{K_{S, S O_{+}}}{\left[S O_{4}^{2-}\right]}\right)}\left(1-\frac{\left[H_{2} S\right]}{K_{I p s}}\right)$ & $\begin{array}{l}\mu_{\text {max.ps }}=0.2025 \mathrm{~d}^{-1} \\
\mathrm{~K}_{\mathrm{S}, \mathrm{ps}}=295 \mathrm{gCOD} \cdot \mathrm{m}^{-3} \\
\mathrm{Y}_{\mathrm{ps}}=0.035 \mathrm{gVSS} \cdot \mathrm{gCOD}^{-1} \\
\mathrm{~K}_{\mathrm{l}, \mathrm{ps}}=285 \mathrm{~g} \mathrm{~S} \cdot \mathrm{m}^{-3} \\
\mathrm{~K}_{\mathrm{S}, \mathrm{SO}}=7.4 \mathrm{gCOD} \cdot \mathrm{m}^{-3}\end{array}$ & $\begin{array}{l}\text { Kinetic constants and sulphide inhibition } \\
\text { from Kalyuzhnyi and Fedorovich (1998) } \\
\left(\mu_{\max } \text { adjusted }\right)\end{array}$ \\
\hline acetogenesis & propionate $\rightarrow$ acetate + hydrogen & $\left.\mu_{a}=\frac{\mu_{\text {max }, a} C_{a}}{\left(1+\frac{K_{S, a}}{[H \operatorname{Pr}]}\left(1+\frac{[H A c]}{K_{l a, H A c}}\right)\right.}\right)\left(1-\frac{\left[H_{2} S\right]}{K_{l a, H_{2} S}}\right)$ & $\begin{array}{l}\mu_{\text {max,a }}=0.04 \mathrm{~d}^{-1} \\
\mathrm{~K}_{\mathrm{S}, \mathrm{a}}=247 \mathrm{gCOD} \cdot \mathrm{m}^{-3} \\
\mathrm{Y}_{\mathrm{a}}=0.018 \mathrm{gVSS} \cdot \mathrm{gCOD}^{-1} \\
\mathrm{~K}_{\mathrm{L}, \mathrm{H} 2 \mathrm{~S} 2}=215 \mathrm{~g} \mathrm{~S} \cdot \mathrm{m}^{-3} \\
\mathrm{~K}_{\mathrm{la}, \mathrm{HAc}}=181 \mathrm{gCOD} \cdot \mathrm{m}^{-3}\end{array}$ & $\begin{array}{l}\text { Kinetic constants and sulphide inhibition } \\
\text { from Kalyuzhnyi and Fedorovich (1998) } \\
\text { Acetate inhibition equation and } \\
\text { constant from Costello et al. (1991) } \\
\left(\mu_{\max } \text { adjusted) }\right.\end{array}$ \\
\hline $\begin{array}{l}\text { aceticlastic } \\
\text { methanogenesis }\end{array}$ & acetate $\rightarrow$ methane & $\mu_{a m}=\frac{\mu_{\text {maxam }} C_{a m}}{\left(1+\frac{K_{S, a m}}{[H A c]}\right)}\left(1-\frac{\left[H_{2} S\right]}{K_{\text {lam }}}\right)$ & $\begin{array}{l}\mu_{\text {max,am }}=0.06 \mathrm{~d}^{-1} \\
\mathrm{~K}_{\mathrm{S}, \mathrm{am}}=56 \mathrm{gCOD} \cdot \mathrm{m}^{-3} \\
\mathrm{Y}_{\text {am }}=0.026 \mathrm{gVSS} \cdot \mathrm{gCOD}^{-1} \\
\mathrm{~K}_{\mathrm{l}, \mathrm{m}}=285 \mathrm{~g} \mathrm{~S} \cdot \mathrm{m}^{-3}\end{array}$ & $\begin{array}{l}\text { Kinetic constants and sulphide inhibition } \\
\text { from Kalyuzhnyi and Fedorovich (1998) } \\
\left(\mu_{\max } \text { adjusted }\right)\end{array}$ \\
\hline $\begin{array}{l}\text { hydrogenotrophic } \\
\text { methanogenesis }\end{array}$ & hydrogen $\rightarrow$ methane & $\mu_{h m}=\frac{\mu_{\max , h m} C_{h m}}{\left(1+\frac{K_{S, h m}}{\left[H_{2}\right]}\right)}\left(1-\frac{\left[H_{2} S\right]}{K_{l h m}}\right)$ & $\begin{array}{l}\mu_{\max , \mathrm{hm}}=0.25 \mathrm{~d}^{-1} \\
\mathrm{~K}_{\mathrm{S}, \mathrm{m}}=0.13 \mathrm{gCOD} \cdot \mathrm{m}^{-3} \\
\mathrm{Y}_{\mathrm{hm}}=0.018 \mathrm{gVSS} \cdot \mathrm{gCOD}^{-1} \\
\mathrm{~K}_{\mathrm{l}, \mathrm{hm}}=215 \mathrm{~g} \mathrm{~S} \cdot \mathrm{m}^{-3}\end{array}$ & $\begin{array}{l}\text { Kinetic constants and sulphide inhibition } \\
\text { from Kalyuzhnyi and Fedorovich (1998) } \\
\left(\mu_{\max } \text { adjusted }\right)\end{array}$ \\
\hline
\end{tabular}




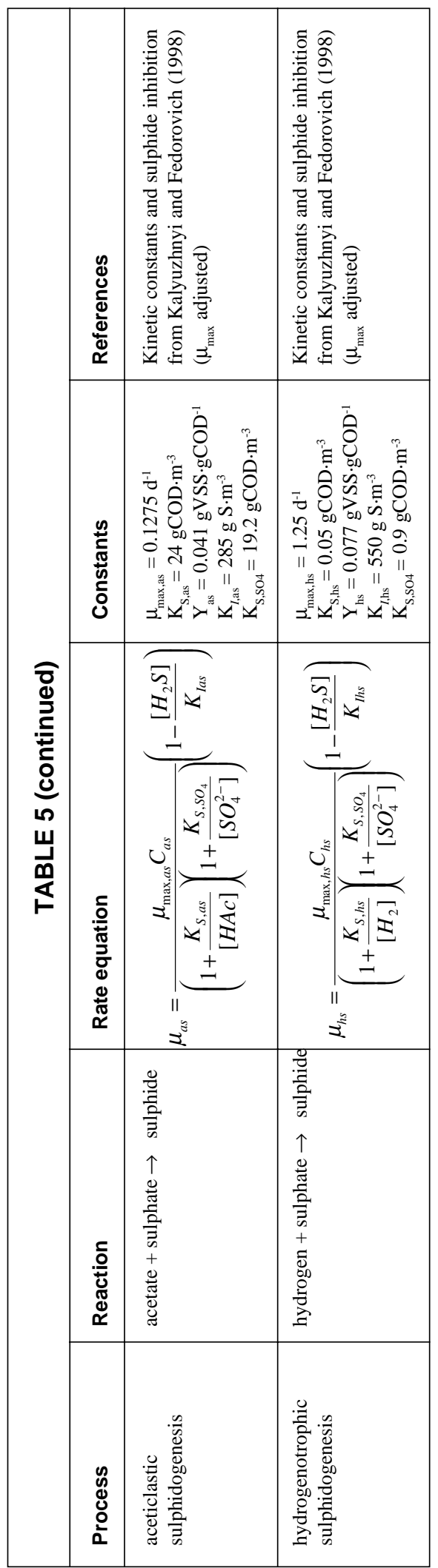

to level off at HRT greater than approximately $1.6 \mathrm{~d}$. Increased sulphate conversion would be expected with an increase in HRT since the amount of particulates being hydrolysed increases, increasing the amount of available organic substrate, and the increased HRT increases the biomass reaction time, and thus reaction time. To explain this inflection point, the rate equation for the specific growth rate of the p$\mathrm{SRB}$ was expanded. The rate equation for the specific growth rate can be written to separate the terms for organic substrate limitation, sulphate substrate limitation, and sulphide inhibition:

$$
\frac{\mu}{\mu_{\max }}=\left(\frac{[H \mathrm{Pr}]}{K_{S}+[H \mathrm{Pr}]}\right)\left(\frac{\left[\mathrm{SO}_{4}^{2-}\right]}{K_{S O_{4}^{2-}}+\left[\mathrm{SO}_{4}^{2-}\right]}\right)\left(1-\frac{\left[\mathrm{H}_{2} S\right]}{K_{\mathrm{H}_{2} S}}\right)
$$

When the concentration of propionate is much higher than the value of the half saturation constant, the term for organic substrate limitation will be close to 1 , and will not affect the value of the specific growth rate in Eq. 1. Similarly, when the sulphate concentration is much higher than the half saturation constant for sulphate, this term will be close to 1 , and when the concentration of undissociated hydrogen sulphide is much lower than the sulphide inhibition constant, the term for sulphide inhibition will be close to 1 . If all three of the above terms are close to 1 , the specific growth rate will be equal to the maximum specific growth rate for the bacteria. Therefore, by calculating the value for each of these terms individually, and then the product of the three terms, the term most affecting the specific growth rate can be determined.

Figure 8 is a plot of the terms for substrate limitation, sulphate limitation, sulphide inhibition, and the product of the three terms, for the acetogenic sulphidogens, as predicted by the model, as the HRT is varied. Figure 8 shows that the values for the sulphate limitation are close to 1 throughout the simulations, suggesting that the bacteria are never sulphate limited. The value for the organic substrate limitation increases with an increase in the HRT. An increase in HRT results in a greater fraction of the feed COD leaving as soluble COD (Fig. 5), and thus the bacteria become less organic-substrate limited at higher HRT.

The sulphide inhibition term decreases with an increase in the HRT, since the sulphate conversion increases, resulting in more sulphide being produced. As this value increases, the bacteria become more inhibited. Of major significance is the fact that the model predicts that the term most affecting the specific growth rate at a HRT of less than $1.5 \mathrm{~d}$ is the organic substrate limitation term, while it is the sulphide inhibition term at a HRT of greater than $1.5 \mathrm{~d}$. This explains the increase in the fraction of the feed COD leaving the bioreactor as soluble COD, shown in Fig. 5.

Figure 6 shows that the model predicts that a SRR of greater than 1 has little effect on the fractions of the various groups. In fact, an extreme SRR of 10 was simulated, and the increase in bioreactor performance with a tenfold increase in SRR was insignificant. However, at an SRR below 1, an inflection point is observed. The fraction of the feed COD leaving as particulate COD decreases, together with a change in the COD being used for sulphate reduction. The trend was simulated for a minimum SRR value of 0.25 . A possible explanation for this is that at lower recycle ratios, there is less of the high density sludge being mixed with the feed, resulting in a lower concentration of particulates in the inlet compartment (Compartment 1, Fig. 4). There are then fewer solids that have to settle out of this liquid stream into the high solids density compartments below, with fewer particles not settling sufficiently, and being washed out of the bioreactor with the effluent stream. This would result in a higher solids retention time than at higher solids recycle ratios, where more solids would be washed out unhydrolysed.

Theoretically, a COD: $\mathrm{SO}_{4}^{2-}$ ratio of 0.67 will result in complete conversion of the sulphate to sulphide, using all the available COD (not taking the production of biomass into account). Figure 7 shows that the majority of the feed COD is leaving the bioreactor as particulate COD. Figure 7 also shows that the fraction of the feed $\mathrm{COD}$ that is leaving as soluble COD is increasing with an increase in the COD: $\mathrm{SO}_{4}^{2-}$ ratio, while the fraction of the feed COD being used for sulphate reduction is decreasing with an increase in the COD: $\mathrm{SO}_{4}^{2-}$ ratio.

The model predicts that as more particulate $\mathrm{COD}$ is added to the bioreactor, more is leaving the bioreactor, with the same fraction being hydrolysed. An increase in the COD: $\mathrm{SO}_{4}{ }_{4}^{2-}$ ratio is a result of more $\mathrm{COD}$ being added, since the $\mathrm{SO}_{4}{ }^{2-}$ concentration is constant. The rate of hydrolysis is first order with respect to the particulate COD 
Matrix representation of the degradation of PSS in the presence of sulphate reduction as used in the model

\begin{tabular}{|c|c|c|c|c|c|c|c|c|c|c|c|c|c|c|c|c|c|c|c|c|}
\hline Process & prot. & cellu. & lipids & SAA & FA & HPr & HAC & $\mathrm{H}_{2}$ & $\mathrm{SO}_{4}$ & $\mathrm{CH}_{4}$ & $\mathrm{H}_{2} \mathrm{~S}$ & $C_{f}$ & $c_{0}$ & $\mathrm{C}_{\mathrm{ps}}$ & $\mathrm{C}_{\mathrm{a}}$ & $\mathrm{C}_{\mathrm{am}}$ & $C_{h m}$ & $\mathrm{C}_{\mathrm{as}}$ & $C_{h s}$ & Process rate \\
\hline $\begin{array}{l}\text { hydrolysis of } \\
\text { proteins }\end{array}$ & -1 & & & +1 & & & & & & & & & & & & & & & & $k_{h_{\text {protein }}} \cdot[$ protein $]$ \\
\hline $\begin{array}{l}\text { hydrolysis of } \\
\text { lipids }\end{array}$ & -1 & & & & +1 & & & & & & & & & & & & & & & $k_{h_{\text {lipids }}}[$ [lipids] \\
\hline $\begin{array}{l}\text { hydrolysis of } \\
\text { cellulose }\end{array}$ & -1 & & & +1 & & & & & & & & & & & & & & & & $k_{h_{\text {cellulose }}} \cdot[$ cellulose $]$ \\
\hline & & & & & & & & & & & & & & & & & & & & $\left(1-\left[H_{2} S\right]\right)$ \\
\hline fermentation & & & & -66 & & +20 & +35 & +11 & & & & & & & & & & & & $\overline{Y_{f}\left(1+\frac{K_{S, f}}{[S A A]}\right)\left(1+\frac{[H A c]}{K_{I f, H A c}}\right)}\left(1-\overline{K_{I f, H_{2} S}}\right)$ \\
\hline $\begin{array}{l}\text { anaerobic } \\
\text { oxidation }\end{array}$ & & & & & -34 & & +23 & +11 & & & & & & & & & & & & $\frac{\mu_{\text {max }, o} C_{o}}{Y_{o}\left(1+\frac{K_{S, o}}{[F A]}\right)}\left(1-\frac{\left[H_{2} S\right]}{K_{I o}}\right)$ \\
\hline $\begin{array}{l}\text { aceticlastic } \\
\text { sulphido- } \\
\text { genesis }\end{array}$ & & & & & & -224 & +128 & & -144 & & 96 & & & & & & & & & $\frac{\mu_{\text {max }, p s} C_{p s}}{Y_{p s}\left(1+\frac{K_{S, p s}}{[H \operatorname{Pr}]}\right)\left(1+\frac{K_{S, S O_{4}}}{\left[S O_{4}^{2-}\right]}\right)}\left(1-\frac{\left[H_{2} S\right]}{K_{I p s}}\right)$ \\
\hline acetogenesis & & & & & & -7 & +4 & +3 & & & & & & & & & & & & $\frac{\mu_{\max , a} C_{a}}{Y_{a}\left(1+\frac{K_{S, a}}{[H \operatorname{Pr}]}\left(1+\frac{[H A c]}{K_{I a, H A c}}\right)\right)}\left(1-\frac{\left[H_{2} S\right]}{K_{I a, H_{2} S}}\right)$ \\
\hline $\begin{array}{l}\text { aceticlastic } \\
\text { methanogenesis }\end{array}$ & & & & & & & -64 & & & +64 & & & & & & & & & & $\frac{\mu_{\max , a m} C_{a m}}{Y_{a m}\left(1+\frac{K_{S, a m}}{[H A c]}\right)}\left(1-\frac{\left[H_{2} S\right]}{K_{\text {Iam }}}\right)$ \\
\hline $\begin{array}{l}\text { hydrogeno- } \\
\text { trophic } \\
\text { methanogenesis }\end{array}$ & & & & & & & & -48 & & +48 & & & & & & & & & & $\frac{\mu_{\max , h m} C_{h m}}{Y_{h m}\left(1+\frac{K_{S, h m}}{\left[H_{2}\right]}\right)}\left(1-\frac{\left[H_{2} S\right]}{K_{I h m}}\right)$ \\
\hline $\begin{array}{l}\text { aceticlastic } \\
\text { sulphidogenesis }\end{array}$ & & & & & & & -64 & & -96 & & +64 & & & & & & & & & $\frac{\mu_{\max , a s} C_{a s}}{Y_{a s}\left(1+\frac{K_{S, a s}}{[H A c]}\right)\left(1+\frac{K_{S, S O_{4}}}{\left[S O_{4}^{2-}\right]}\right)}\left(1-\frac{\left[H_{2} S\right]}{K_{\text {Ias }}}\right)$ \\
\hline
\end{tabular}


TABLE 6 (continued)

\begin{tabular}{|c|c|c|c|c|c|c|c|c|c|c|c|c|c|c|c|c|c|c|c|c|}
\hline Process & prot. & cellu. & lipids & SAA & FA & $\mathrm{HPr}$ & HAC & $\mathbf{H}_{2}$ & $\mathrm{SO}_{4}$ & $\mathrm{CH}_{4}$ & $\mathrm{H}_{2} \mathrm{~S}$ & $C_{f}$ & $c_{0}$ & $C_{p s}$ & $c_{a}$ & $\mathrm{C}_{\mathrm{am}}$ & $C_{h m}$ & $\mathrm{C}_{\text {as }}$ & $\mathrm{c}_{\mathrm{hs}}$ & Process rate \\
\hline $\begin{array}{l}\text { hydrogenotrophic } \\
\text { sulphidogenesis }\end{array}$ & & & & & & & & -64 & -96 & & +64 & & & & & & & & & $\frac{\mu_{\max , h s} C_{h s}}{Y_{h s}\left(1+\frac{K_{S, h s}}{\left[H_{2}\right]}\right)^{\left(1+\frac{K_{S, S O_{4}}}{\left[S O_{4}^{2-}\right]}\right.}}\left(1-\frac{\left[H_{2} S\right]}{K_{l h s}}\right)$ \\
\hline $\begin{array}{l}\text { growth of } \\
\text { fermentors }\end{array}$ & & & & & & & & & & & & +1 & & & & & & & & $\frac{\mu_{\max , f} C_{f}}{\left(1+\frac{K_{S, f}}{[S A A]}\right)\left(1+\frac{[H A c]}{K_{I f, H A c}}\right)}\left(1-\frac{\left[H_{2} S\right]}{K_{I f, H_{2} S}}\right)$ \\
\hline oxidisers & & & & & & & & & & & & & +1 & & & & & & & $\frac{\mu_{\max , o} C_{o}}{\left(1+\frac{K_{S, o}}{[F A]}\right)}\left(1-\frac{\left[H_{2} S\right]}{K_{I o}}\right)$ \\
\hline $\begin{array}{l}\text { growth of } \\
\text { aceticlastic } \\
\text { sulfidogens }\end{array}$ & & & & & & & & & & & & & & +1 & & & & & & $\frac{\mu_{\max , p s} C_{p s}}{\left(1+\frac{K_{S, p s}}{[H \mathrm{Pr}]}\right)\left(1+\frac{K_{S, S O_{4}}}{\left[S O_{4}^{2-}\right]}\right)}\left(1-\frac{\left[H_{2} S\right]}{K_{l p s}}\right)$ \\
\hline $\begin{array}{l}\text { growth of } \\
\text { acetogens }\end{array}$ & & & & & & & & & & & & & & & +1 & & & & & $\frac{\mu_{\max , a} C_{a}}{\left(1+\frac{K_{S, a}}{[H \operatorname{Pr}]}\left(1+\frac{[H A c]}{K_{I a, H A c}}\right)\right)}\left(1-\frac{\left[H_{2} S\right]}{K_{I a, H_{2} S}}\right)$ \\
\hline $\begin{array}{l}\text { growth of } \\
\text { aceticlastic } \\
\text { methanogens }\end{array}$ & & & & & & & & & & & & & & & & +1 & & & & $\frac{\mu_{\max , a m} C_{a m}}{\left(1+\frac{K_{S, a m}}{[H A c]}\right)}\left(1-\frac{\left[H_{2} S\right]}{K_{\text {lam }}}\right)$ \\
\hline $\begin{array}{l}\text { growth of } \\
\text { hydrogenotrophic } \\
\text { methanogens }\end{array}$ & & & & & & & & & & & & & & & & & +1 & & & $\frac{\mu_{\text {max } h m} C_{h n}}{\left(1+\frac{K_{S, h m}}{\left[H_{2}\right]}\right)}\left(1-\frac{\left[H_{2} S\right]}{K_{l h m}}\right)$ \\
\hline $\begin{array}{l}\text { growth of } \\
\text { aceticlastic } \\
\text { sulfidogens }\end{array}$ & & & & & & & & & & & & & & & & & & +1 & & $\frac{\mu_{\max , a s} C_{a s}}{\left(1+\frac{K_{S, a s}}{[H A c]}\right)\left(1+\frac{K_{S, S O_{4}}}{\left[S O_{4}^{2-}\right]}\right)}\left(1-\frac{\left[H_{2} S\right]}{K_{\text {las }}}\right)$ \\
\hline $\begin{array}{l}\text { growth of } \\
\text { hydrogenotrophic } \\
\text { sulfidogens }\end{array}$ & & & & & & & & & & & & & & & & & & & +1 & $\frac{\mu_{\max , h s} C_{h s}}{\left(1+\frac{K_{S, h s}}{\left[H_{2}\right]}\right)\left(1+\frac{K_{S, S O_{4}}}{\left[S O_{4}^{2-}\right]}\right)}\left(1-\frac{\left[H_{2} S\right]}{K_{I h s}}\right)$ \\
\hline
\end{tabular}


concentration, and at higher feed concentrations, the rate of hydrolysis would increase. The higher reaction rate would cause greater conversion of the reactants for the same reaction time (HRT). The overall result is that more soluble COD is produced with an increase in the COD: $\mathrm{SO}_{4}{ }^{2-}$ ratio.

\section{Sensitivity analysis}

The results of a sensitivity analysis on the kinetic constants in the model indicate that the first-order hydrolysis constant for the proteins, lipids and cellulose respectively are most critical to the model outputs. This is expected, since the aim of the FSBR is to hydrolyse the particulate organic matter, and the settling and recycle of the solids fraction allows for greater solids residence times, and greater solids concentrations. The value of the hydrolysis rate constants, and in fact the form of the hydrolysis rate equation, is the most critical factor in modelling the FSBR. The sensitivity analysis also shows that the sulphide inhibition constants are most critical to the biological reactions. The settling coefficients and the feed COD have most influence on the outputs of the model and indicate that hydrolysis is the most critical process in the FSBR.

\section{Conclusions and future work}

This is the first mathematical model that includes hydrolysis of particulate organic matter and biological sulphate reduction. Although rate equations and kinetic constants are available in the literature, investigation of certain critical processes is required before a more accurate model can be developed. Kinetic studies should focus on the hydrolysis of primary settled sewage under sulphate-reducing conditions and at reduced temperatures. The modelling of sulphide inhibition of the bacterial species needs further investigation

AQUASIM is able to simulate the settling of the particulates in the FSBR, and is adequate in modelling such a system. However, vapour-liquid equilibria and acid-base equilibria need to be included in the model, so that $\mathrm{pH}$ variations in the system can be simulated.

The model underestimates the hydrolysis conversion in the FSBR since it does not include $\mathrm{pH}$, sulphate and temperature effects. The model is useful for predicting trends only. Results of the above-mentioned experimental work would allow for the development of a more predictive model, and allow for accurate prediction of the overall plant performance, allowing for integration and optimisation of the unit operations.

\section{Acknowledgements}

This work was supported by the Water Research Commission of South Africa.

\section{References}

BRAUN M AND STOLP H (1985) Degradation of methanol by a sulphate reducing bacterium. Arch. Microbiol. $58786-793$

BURGESS SG and WOOD LB (1961) Pilot plant studies in production of sulphur from sulphate enriched sewage sludge. J. Sci. Food Agric. 12 $326-341$.

BUTLIN KR, SELWYN SC and WAKERLEY DS (1956) Sulphide production from sulphate enriched sewage sludges. J. Appl. Bacteriol. $193-15$.
CHRISTENSEN B, LAAKE M and LIEN T (1996) Treatment of acid mine water by sulphate reducing bacteria: Results from a bench scale experiment. Water Res. 30 (7) 1617 - 1624.

CONRADIE PJA and GRUTZ PWE (1973) The Treatment of Acid Mine Waste in a Mixture with Sewage Sludge in an Aerobic Digester. Report to the Chamber of Mines (File No w6/534/3). National Institute for Water Research, Pretoria.

COSTELLODJ, GREENFIELDPFand LEEPL(1991)Dynamic modelling of a single stage high rate anaerobic reactor. Water Res. 25 (7) $847-$ 871.

DU PREEZ LA, ODENDAAL JP, MAREE JP and PONSONBY M (1992) Biological removal of sulphate from industrial effluents using producer gas as an energy source. Environ. Technol. $13 \quad 875-882$.

EASTMAN JA and FERGUSON JF (1981) Solubilisation of particulate organic carbon during the acid phase of anaerobic digestion. J. WPCF 53 (3) $352-366$.

GUJER W and ZEHNDER AJB (1983) Conversion processes in anaerobic digestion. Water Sci. Technol. 15127 - 167.

KALYUZHNYI SV and FEDOROVICH VV (1998) Mathematical modelling of competition between sulphate reduction and methanogenesis in anaerobic reactors. Biodegradation $9187-199$.

KASPER HF and WUHRMANN K (1977) Kinetic parameters and relative turnover of some important catabolic reactions in digesting sludge. Appl. Environ. Microbiol. 36 (1) 1 - 7.

KHAN AW and TROTTIER TM (1978) Effect of sulphur-containing compounds on anaerobic degradation of cellulose to methane by mixed cultures obtained from sewage sludge. Appl. Environ. Microbiol. 35 (6) $1027-1034$.

MAREE JP and HILL E (1989) Biological removal of sulphate from industrial effluents and concomitant production of sulphur. Water Sci. Technol. $21265-276$.

MUSVOTO EV, WENTZEL MC, LOEWENTHAL RE and EKAMA GA (1997) Kinetic-based model for mixed weak acid/ base systems. Water SA 23 (4) 311 - 322

NOVAK JT and CARLSON DA (1970) The kinetics of anaerobic long chain fatty acid degradation. J. WPCF 421932 - 1943.

OLESZKIEWICZ JA and HILTON BL (1986) Anaerobic treatment of high sulphate wastes. Can. J. Civ. Eng. $13423-428$.

O'ROURKE JT (1968) Kinetics of Anaerobic Treatment at Reduced Temperatures. PhD Thesis, Dept. Civ. Eng., Stanford Univ.

PAREEK S, KIM SK, MATSUI S and SHIMUZU Y (1998) Hydrolysis of (ligno)cellulosic materials under sulphidogenic and methanogenic conditions. Water Sci. Technol. 38 (2) 193 - 200.

PIPES OW (1960) Sludge digestion by sulphate-reducing bacteria. Proc. the $15^{\text {th }}$ Ind. Waste Conf., Purdue Univ., Lafayette, Indiana.

POSTGATE JR (1984) The Sulphate Reducing Bacteria. Cambridge University Press, Cambridge.

RIECHERT P (1994) AQUASIM - A tool for simulation and data analysis of aquatic systems. Water Sci. Technol. 30 (2) $21-30$.

SZEWZYK R and PFENNIG N (1990) Competition for ethanol between sulphate reducing and fermenting bacteria. Arch. Microbiol. 153470 $-477$.

UEKI K, KOTAKA K, ITOH K and UEKI A (1988) Potential availability of anaerobic treatment with digester slurry of animal waste for the reclamation of acid mine water containing sulphate and heavy metals. J. Ferment. Technol. $6643-50$.

VAN HOUTEN RT, HULSHOFF POL LW and LETTINGA G (1994) Biological sulphate reduction using gas-lift reactors fed with hydrogen and carbon dioxide as energy and carbon source. Biotech. Bioeng. 44 $586-594$.

WITTINGTON-JONES K (1999) Enhanced Hydrolysis of Primary Settled Sewage under Sulphide Rich Conditions. PhD Thesis, Dept. Biochem. \& Microbiol., Rhodes Univ. 